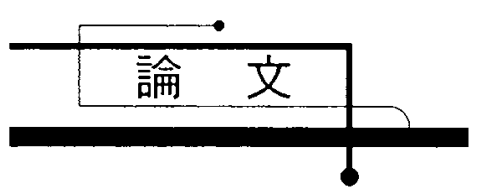

\title{
気水分離器における液相分離部が気液分離性能に及ぼす影響*
}

\section{Effects of Liquid-Separation Components on Separation Performance of a Steam Separator}

\author{
上遠野 健 一 ${ }^{* *} \dagger$ \\ KATONO Kenichi
}

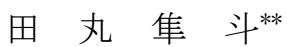 \\ TAMARU Hayato
}

\author{
細川茂 雄** \\ HOSOKAWA Shigeo
}

\author{
林公 祐** 冨山明男** \\ HAYASHI Kosuke \\ TOMIYAMA Akio
}

\begin{abstract}
A downscaled model of a steam separator is used to understand characteristics of swirling flow and to investigate the effects of geometry of separator components on separation performance. Main conclusions obtained are as follows. (1) Separation performance improves with the gas volume flux. However carryunder, i.e. the weight percentage of entrained gas in the water leaving the separator, tends to be lower as the liquid film thickness becomes thinner under low liquid volume flux conditions. (2) The ratio of the flow rate of separated liquid to the total liquid flow rate does not depend on the liquid volume flux so much. On the other hand, the carryunder becomes lower with the liquid volume flux. (3) An improved pick-off ring, whose gap width is about the maximum liquid film thickness and sudden expansion is mitigated by a diffuser, effectively reduces the pressure drop while keeping high separation performance.
\end{abstract}

Keywords: Steam separator, Two-phase flow, Swirling flow, Pick-off Ring (POR) Advanced Boiling Water Reactor (ABWR)

\section{1. 緒 言}

改良型沸騰水型原子炉 ABWR（Advanced Boiling Water Reactor）の気水分離器は、流路内に 固定されたスワラーにより炉心で発生した蒝気 と水の気液二相流に旋回力を与え、遠心分離作用 により密度の大きい水を外側へ集めて複数段の ピックオフリング (Pick-off Ring: POR) により気 水分離器外部一押し出し、密度の小さい蒸気を流 路中央一集めて上方出口から蒸気乾燥器へ送り 出于[1]。気水分離器は冷却水の再循環経路に含ま れるため、気水分離器の圧力損失低減により、密 度波振動防止や再循環系ポンプの負荷低減、原子 カプラントの電気出力向上など、ABWR の安全 性及び経済性の向上が期待できる。
気水分離器の圧力損失低減を目的亡した過去 の研究には、機器評価指標である気液分離性能と 圧力損失から気水分離器の改良方法を検討した 研究[2-6]が多いが、内部流動の把握に基づく研究 例は少ない。一方、片岡ら[7-10]は気水分離器の 第 1 段分離部までを模擬した約 $1 / 5$ スケール試験 装置内の空気-水系旋回二相流を対象に、流動状 態、液膜厚さ、液相分離率、液滴分布、圧力損失 を測定し、気水分離器構成要素の寸法や形状が気 水分離器の性能及び旋回二相流の流動状態に及 ぼす影響を調べている。しかし、第 1 段分離部以 降の第 $2 、$ 第 3 段分離部を含む気液分離特性に及 ぼす構成要素の影響を検討した例はほとんどな い。そこで、本研究では、気水分離器の第 2 段分

* 2015.7.10 受付

** 神戸大学大学院 干657-8501 神戸市灘区六甲台町 1-1

†株式会社日立製作所 研究開発グループ エネルギーイノベーションセンタ

干319-1292 茨城県日立市大夕か町七丁目 1 番 1 号

TEL: (0294)55-8088 FAX: (0294)55-9973 E-mail: kenichi.katono.kq@hitachi.com 
離部までを模擬した縮小試験装置を用いて、流動 状態、液相分離率、液膜厚さ、キャリーアンダー

(分離液相と共に排出される気相の質量流量割 合)、圧力損失を測定し、気水分质器の構成要素 である POR の形状が気液分䧹特性に及ぼす影響 を検討した。

\section{2. 気水分離器内旋回二相流動模擬試験}

\section{1 試験装置}

Fig. 1 に試験装置の概略を示す。試験装置は、 気液混合部、プレナム、気水分離器模擬試験部、 試験部貯水タンク、キャリーアンダー測定容器、 上部タンク、下部貯水タンク、水及び空気の供給 系で構成されている。試験部は実機を約 $1 / 5$ に縮 小したスケールダウンモデルであり、スタンドパ イプ、スワラー、バレル、第 1 段 POR、第 2 段 POR 及び排水流路からなる。第 1 段 POR 下部の バレル及びスタンドパイプは二重円筒となって おり、中心流路が気水分離器内流路、外側の環状 流路が排水流路を模擬している。Fig. 2 に示す八 ブと 8 枚の固定羽根からなるスワラーにより旋 回力を加えられた気液二相流は旋回しながらバ レル内を上昇し、第 1 段 POR で液相の一部が分 離される。分離された液相は排水流路を通過し試 験部貯水タンクを経て下部貯水タンクへ戻る。第 1 段 POR において分離しきれなかった液相と気 相は旋回しながらバレル内を上昇し、第 2 段 POR により再度気液分雇され、下部貯水タンクに戻る。

Fig. 3 に基準とした POR の概略を示す。第 1 段 POR は内径 $32 \mathrm{~mm}$ 、肉厚 $0.6 \mathrm{~mm}$ であり、バレ ル内壁と POR 外壁の間隔（以下、ギャップ幅） は3.4 mmである。また、第2段PORは内径 $35 \mathrm{~mm}$ 、 肉厚 $0.6 \mathrm{~mm}$ であり、ギャップ幅は $1.9 \mathrm{~mm}$ である。

\section{2 試験条件}

縮小試験装置を用いて実機気水分離器の圧力 損失及び気水分離性能を評価するためには、クオ リティと二相遠心力を一致させることが有用て ある[6]。本試験は、出力密度を増加した ABWR の定格運転時のクオリティと二相遠心力に一致 する条件 (バレル内気相体積流束 $J_{G}=14.6 \mathrm{~m} / \mathrm{s}$, バレル内液相体積流束 $J_{L}=0.08 \mathrm{~m} / \mathrm{s}$ ) [7]を包含す るように、 $J_{G}=12.0 、 14.6 、 17.8 \mathrm{~m} / \mathrm{s}$ の 3 条件、 $J_{L}$ $=0.05 、 0.08 、 0.11 \mathrm{~m} / \mathrm{s}$ の 3 条件で行った。なお、 試験部貯水タンクの水位は、排水流路出口に加わ る静水圧と試験部内部の全圧との比が実機体系
と一致するように、排水流路出口より $5 \mathrm{~mm}$ 高い 位置に設定した。

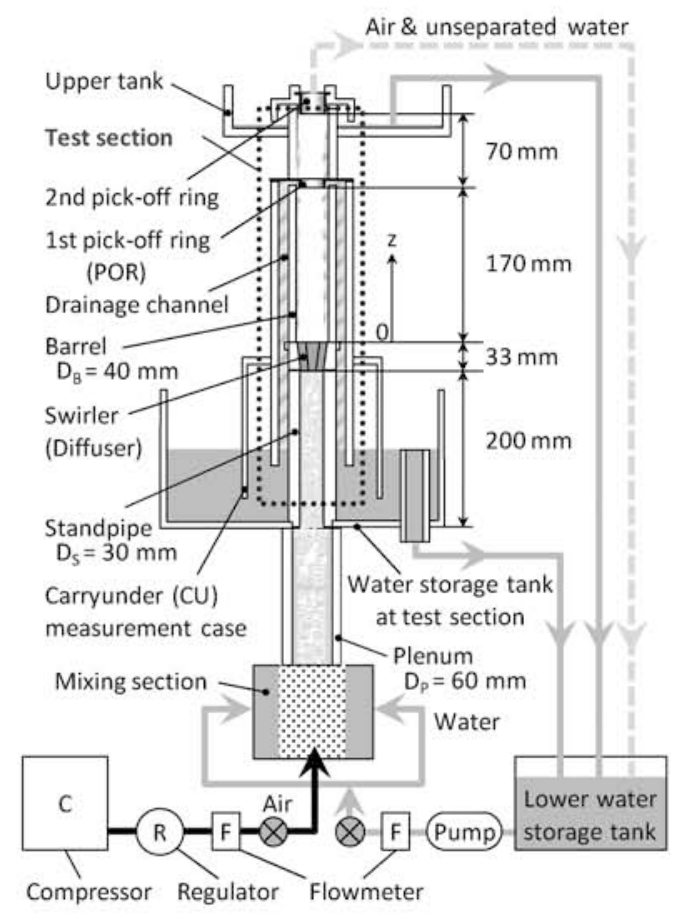

Fig. 1 Experimental apparatus.

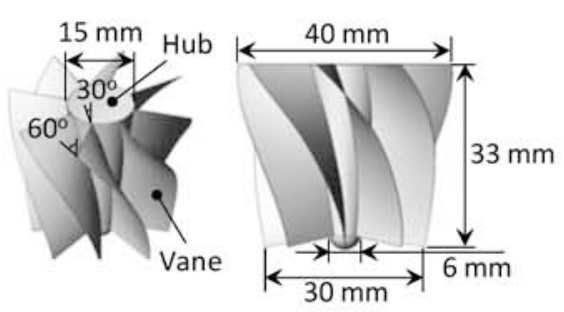

Fig. 2 Swirler shape.

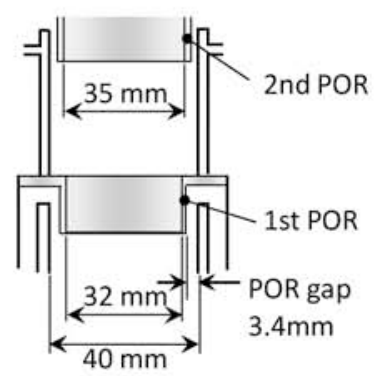

Fig. 3 Normal POR (gap $3.4 \mathrm{~mm}$ ). 


\section{3 測定方法}

試験部内における流動状態の可視化には、高速 度ビデオカメラ (Redlake, Motion Pro X-3) を用い た。第 1 段 POR 通過後のバレル内流動をバレル 外部側方から撮影 (画素数 : $900 \times 500$ pixel、フ

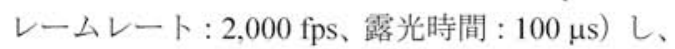
また、高速度ビデオカメラに接続したボアスコー プ (OLYMPUS, R080-084-000-50) を試験部上方 からバレル内に挿入して撮影した（画素数： 400 $\times 400$ pixel、フレームレート : 1,000 fps、露光時 間: $900 \mu \mathrm{s})$ 。

第 1 段 POR における液相分離率 $W_{s}^{*}, 1$ 、第 2 段 POR における液相分離率 $W_{s}^{*}, 2$ 、及び、合計の液 相分離率 $W_{s}^{*}{ }_{T}$ は以下の諸式で定義される。

$$
\begin{aligned}
& W_{s, 1}^{*}=\frac{W_{L s, 1}}{W_{L s, 1}+W_{L s, 2}+W_{L u s}} \\
& W_{s, 2}^{*}=\frac{W_{L s, 2}}{W_{L s, 1}+W_{L s, 2}+W_{L u s}} \\
& W_{s, T}^{*}=\frac{W_{L s, 1}+W_{L s, 2}}{W_{L s, 1}+W_{L s, 2}+W_{L u s}}
\end{aligned}
$$

ここで、 $W_{L s, 1}$ 及び $W_{L s, 2}$ は各々第 1 段及び第 2 段 PORにおける分陮液相質量流量であり、秥U は未 分離液相質量流量である。分離液相体積流量及び 未分離液相体積流量は受け止め法により計測し、 $\left(W_{L s, 1}+W_{L s, 2}+W_{L u s}\right)$ と供給液相質量流量との差は $\pm 1 \%$ 以内であった。

第 1 段 POR 下流におおる液膜厚さの測定には、 レーザフォーカス変位計 (KEYENCE, LT9030M) を用いた。計測位置である第 1 段 POR 下流のバ レル外壁面を平面に加工することで、レーザビー ムの屈折に伴う測定誤差を低減した[11]。液膜厚 さ計測の空間分解能は $0.1 \mu \mathrm{m}$ 、サンプリング周期 は $0.64 \mathrm{~ms}$ で、測定点数は 50,000 点とした。なお、 測定值の平均值の不確かさは $1 \%$ あっあた。

キャリーアンダー $(C U)$ は以下の式で定義さ れる。

$$
C U=\frac{W_{G s, 1}}{W_{G s, 1}+W_{L s, 1}}
$$

ここで、 $W_{G s, 1}$ は第 1 段 POR における分離気相質 量流量であり、排水流路から排出された分灕気相 をキャリーアンダー測定容器に回収し、容器上部
に接続したチューブから気相を取り出し、水上置 換による受け止め法により 5 回計測した。 5 回の 計測值の標淮偏差は平均値に対して $1.6 \%$ 以下で あった。

試験部内圧力分布 $P_{z}(z=-183,-83,-36,50,150$, $212 \mathrm{~mm} 、 z$ はバレル下端を基準とした高さ）は、 圧力測定用タップに微差圧トランスデューサ

(Valydine, DP45) を接続して測定した。この機 器の計測精度は土 $0.5 \%$ である。圧力計測時のサン プリング周波数は $1.0 \mathrm{kHz}$ 、測定点数は 50,000 点 とした。なお、第 1 段 POR 先端位置が $z=170 \mathrm{~mm}$ であるため、第 1 段 POR における圧力損失は $P_{150}$ $\sim P_{212}$ 間の差圧として評価した。

\section{3. 試験結果及び考察}

\section{1 流動状態}

Fig. 4 に第 1 段 POR 通過後の試験部内、Fig. 5 に第 1 段 POR 下流のバレル内流動の可視化結果 を示す。試験条件は共に $J_{G}=14.6 \mathrm{~m} / \mathrm{s} 、 J_{L}=0.08$ $\mathrm{m} / \mathrm{s}$ である。Fig. 4 より、 $t=0 \mathrm{~ms}$ では試験部内の 液相は旋回力により壁面に集積して液膜となっ ておりガスコア内には液滴が見られないが、 $t=$ $10 \mathrm{~ms}$ では液膜の一部が第 1 段 PORを乗り越える 際に大量の液滴が飛散している様子を確認でき る。また、Fig. 5 より、第 1 段 POR 通過時に飛散 した液滴がガスコア内を移動している様子や、旋 回力によってバレル壁面の液膜に再付着してい る液滴も確認できる。

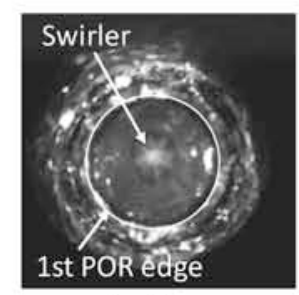

$\mathrm{t}=0 \mathrm{~ms}$

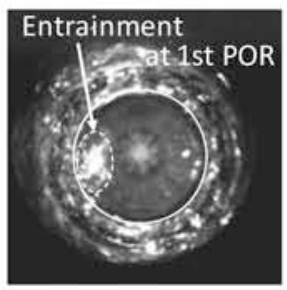

$\mathrm{t}=10 \mathrm{~ms}$

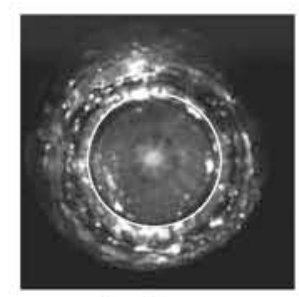

$\mathrm{t}=5 \mathrm{~ms}$

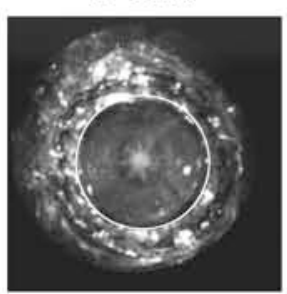

$\mathrm{t}=15 \mathrm{~ms}$
Fig. 4 Flow pattern in the test section. 


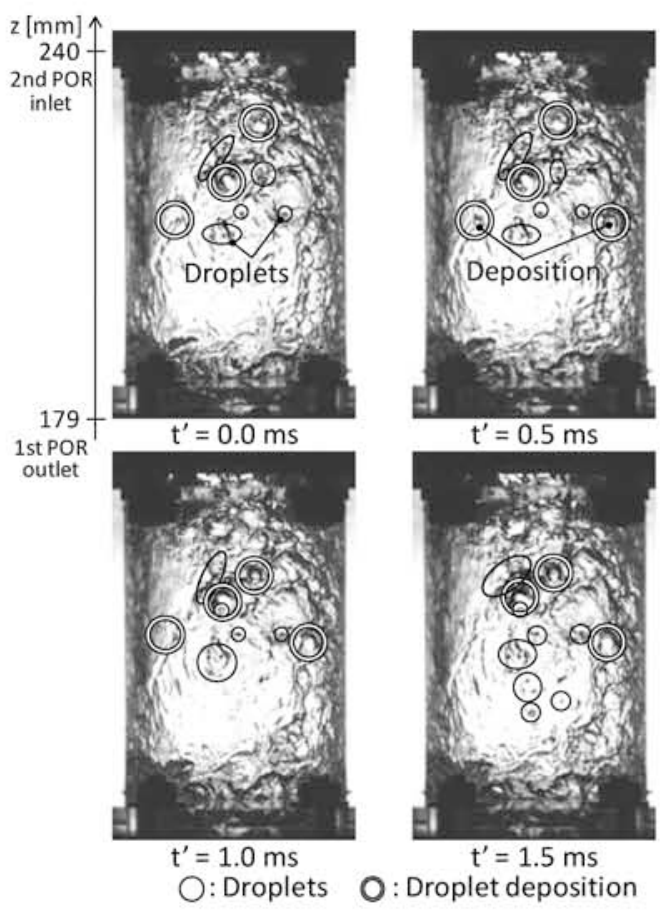

Fig. 5 Flow pattern after passing through 1st POR.

\section{2 液相分離率}

Fig. 6 に各 $J_{G}$ 及び $J_{L}$ における液相分離率を示 す。 $J_{G}$ の増加に伴い $W_{s, 1}^{*}$ は増加している。これ は $J_{G}$ 増加により界面せん断力が増加し、液膜が 薄くなる[7]ことで第 1 段 POR のギャップ部に液 相が流入しやすくなったためである。一方、 $J_{G}$ 増加に伴い $W_{s}{ }^{*}{ }_{2}$ は減少している。これは $J_{G}$ 増加 により $W_{s}^{*}, 1$ が増加し、第 1 段 POR 下流に残留す る液相流量が減少したためである。 $J_{G}$ が増加する と $W_{S}{ }^{*}{ }_{T}$ は僅かに増加している。これは $J_{G}$ 増加に より旋回力が強くなり、液滴の壁面一の付着が促 進されたこと、及び、第 1 段 POR における分離 率が大きく、第 1 段 POR を乗り越える際の液滴 飛散が少ないことが原因と考えられる。

一方、 $J_{L}$ が増加しても $W_{s, 1}^{*}$ はほぼ一定である。 このことから $J_{L}$ が増加しても第 1 段 POR 上流に おける液膜流量と液滴流量の比が変化していな いと考えられる。また、 $J_{L}$ の増加に伴い $W_{s}^{*}{ }_{2}$ 及 び $W_{s}^{*}{ }_{T}$ は僅かに減少している。これは $J_{L}$ 増加に より第 1 段 POR を乗り越える液膜流量及び第 1 段 POR 部で飛散する液滴量が増加し、第 2 段 POR で分離されずにそのまま通過する液相が増加し たためといえる。

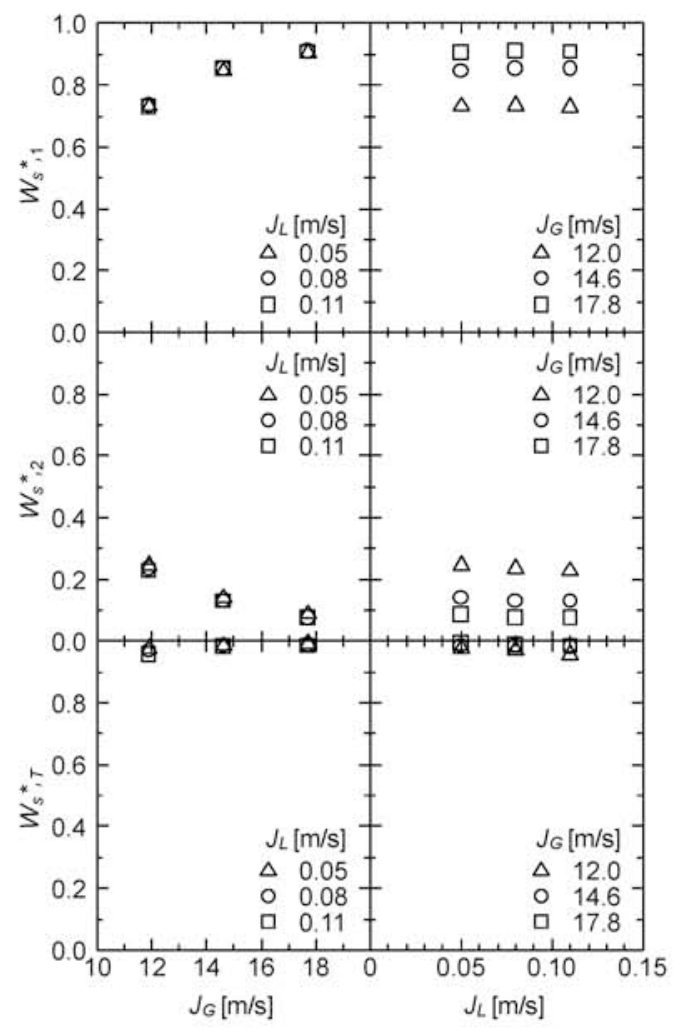

Fig. 6 Effects of $J_{G}$ and $J_{L}$ on $W_{s}^{*}$.

\section{3 液膜厚さ}

Fig. 7 に第 1 段 POR 下流における液膜厚さ測定 值の平均值 $\delta_{m}$ を示寸。 $J_{L}=0.08 \mathrm{~m} / \mathrm{s}$ において、 $J_{G}$ の増加に伴い $\delta_{m}$ は減少している。これは 3.2 節で 述べたように、 $J_{G}$ の増加に伴って $W_{s}^{*}$, が増加し、 第 1 段 POR 下流の液相流量が減少したこと、及 び、界面せん断力が増加したことによるものと考 えられる。なお、 $z=200 \mathrm{~mm}$ 付近において液膜厚 さが下流側よりも厚いのは、第 1 段 POR 背面に 生じている液溜まりの影響である。

一方、 $J_{G}=14.6 \mathrm{~m} / \mathrm{s}$ において、 $J_{L}$ の増加に伴い $z=200 \mathrm{~mm}$ 付近における液膜厚さが減少してい る。これは $J_{L}$ の増加により第 1 段 POR を乗り越 える際に飛散する液滴量が増加寸るためといえ る。また、第 2 段 POR 先端位置 $(z=240 \mathrm{~mm})$ に おける液膜厚さには $J_{L}$ の影響はほとんどみられ ない。以上より、 $J_{L}$ が増加寸ると第 1 段 POR 下 流における液滴流量割合が増加し、3.2 節で述心゙ たように、 $W_{s, 2}^{*}$ 及び $W_{s}^{*}, T$ が僅かに減少する要因 となっていると考えられる。 


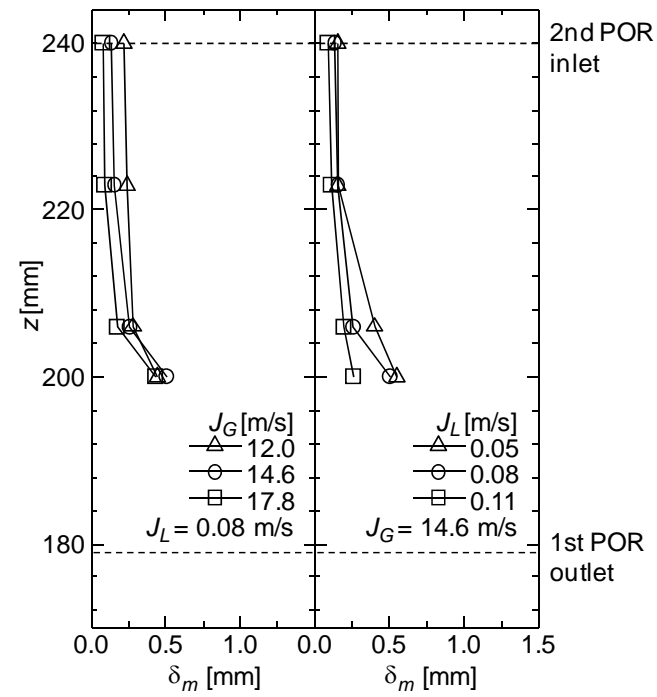

Fig. 7 Film thickness in the downstream of 1st POR.

\section{4 キャリーアンダー}

Fig. 8 に各 $J_{G}$ 及び $J_{L}$ における $C U$ を示す。 $J_{G}$ が $12.0 \mathrm{~m} / \mathrm{s}$ から $14.6 \mathrm{~m} / \mathrm{s}$ に増加すると $C U$ は減少 し、 $14.6 \mathrm{~m} / \mathrm{s}$ から $17.8 \mathrm{~m} / \mathrm{s}$ に増加すると $C U$ は増 加する傾向がある。 $J_{G}$ 増加により、バレル部にお ける旋回力が強くなることで気液分離は促進さ れ、バレル内壁面を旋回しながら上昇する液膜内 に同伴される気相割合は減少する。一方、界面せ 几断力の増加により液膜厚さが薄くなることで、 特に $J_{L}$ が低い条件において POR ギャップ部から 排水流路への気相流入が増加し、 $J_{G}=17.8 \mathrm{~m} / \mathrm{s}$ で $C U$ が増加する傾向を示したものと考えられる。

また、 $J_{L}$ の増加に伴いCUが減少している。こ れは $J_{L}$ 増加により液膜が厚くなるため、排水流 路への気相流入が抑制されたためと考えられる。

\section{5 軸方向圧力分布}

Fig. 9 に次式で定義される無次元圧力 $P^{*}$ を示す。

$$
P^{*}=\frac{P_{z}-P_{212}}{P_{212}}
$$

ここで、 $P_{212}$ は最下流側の計測位置 $(z=212 \mathrm{~mm})$ における圧力である。

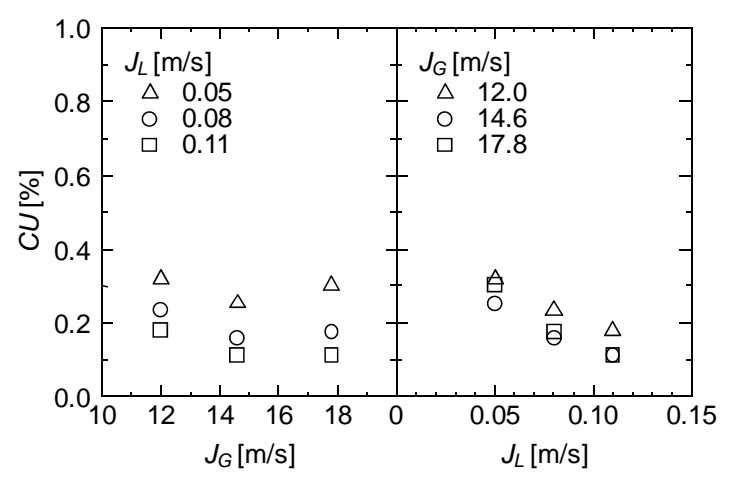

Fig. 8 Effects of $J_{G}$ and $J_{L}$ on $C U$.

スワラーが装着されているディフューザ部で は内径が $30 \mathrm{~mm}$ から $40 \mathrm{~mm}$ へと拡大されている ため、ディフューザ下流において圧力回復が生じ ると考えられる。しかし、ディフューザ部での $P^{*}$ の勾配は、圧力回復がなく摩擦損失による圧力 損失が生じるバレル部と同程度であり、このこと から、スワラーによる圧力損失は、流路拡大によ る圧力回復よりも大きいことがわかる。また、第 1 段 POR を含む区間での $P^{*}$ の勾配も大きい。こ れは、液相分離に伴う運動量損失に加え、POR 入口部では流路面積の急縮小、出口部では急拡大 があるため局所損失が生じ、比較的大きな圧力損 失となるためと考えられる。なお、局所圧力損失 の影響が大きいと考えられるスワラー部及び第 1 段 POR 部における $P^{*}$ の勾配は、 $J_{G}$ に強く依存し ている。

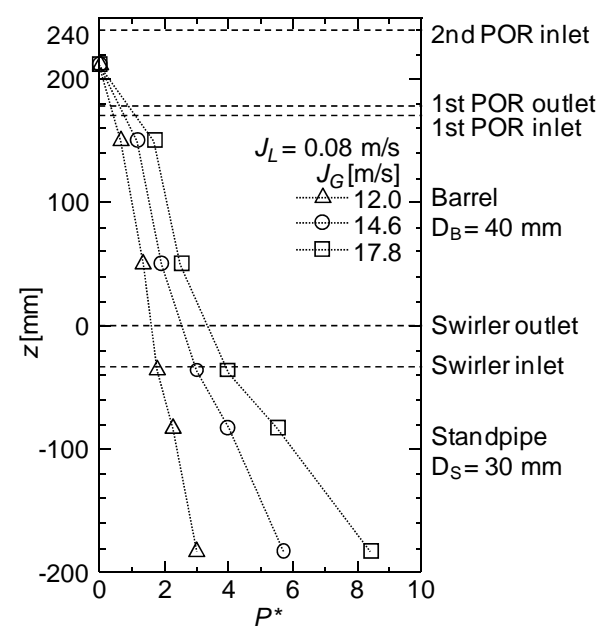

Fig. 9 Axial distribution of $P^{*}$. 


\section{4. ピックオフリングの改良}

\section{1 改良型ピックオフリング}

3.5 節の検討から、気水分離器の圧力損失低減 には、スワラー及び POR 形状の改良が有効であ ることがわかる。著者らはこれまでにスワラー形 状改良による低圧損型気水分離器の検討をして いる[10]。以下では、気水分離器の第 2 段分離部 までを模擬した縮小試験装置を用いて、第 1 段 POR 形状の改良を検討し、気液分離性能や圧力損 失に及ぼす影響を調べた結果を示す。

Fig. 10 に改良型 POR の概略を示す。改良型 POR のギャップ幅は既報[9]において測定した第 1 段 POR 位置における定格運転相当条件 $\left(J_{G}=\right.$ $14.6 \mathrm{~m} / \mathrm{s} 、 J_{L}=0.08 \mathrm{~m} / \mathrm{s}$ ) 時の最大液膜厚さに相当 する $2.2 \mathrm{~mm}$ とし、Fig. 3 に示した基準 POR (Normal)のギャップ幅 $(3.4 \mathrm{~mm})$ よりも狭くした。 また、POR 出口部での局所圧力損失低減を狙い、 POR 下流流路形状を急拡大流路からディフュー ザに変更した。ディフューザ高さは単相流におけ るディフューザ性能線図[12]を用いて流れの剥離 が生じない条件となるように決定した。なお、本 研究では第 2 段 POR 形状は変更していない。

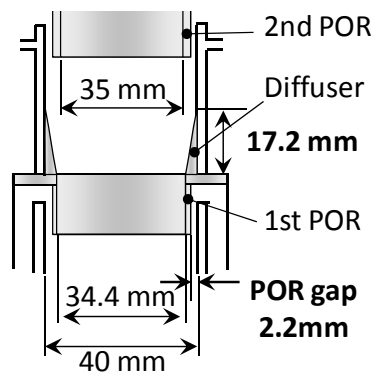

Fig. 10 Improved POR.

以下では、ギャップ幅とディフューザ部のそれ ぞれの効果を調べるために、ギャップ幅のみを変 更した POR (R-Gap) と、さらにディフューザ部も 設けた POR (Improved)の性能を調べた。

Table 1 Type of PORs.

\begin{tabular}{c|c|c|c}
\hline POR type & $\begin{array}{c}\text { POR gap } \\
{[\mathrm{mm}]}\end{array}$ & Diffuser & Figure \\
\hline Normal & 3.4 & - & Fig. 3 \\
\hline R-Gap & 2.2 & - & - \\
\hline Improved & 2.2 & $\bigcirc$ & Fig. 10 \\
\hline
\end{tabular}

\section{2 性能評価}

Fig. 11 に第 1 段 POR 部圧力損失 $\Delta P$ を示す。 $J_{G}$ 増加に伴い $\Delta P$ は増加している。これはギャップ 幅が液膜厚さより大きいため、第 1 段 POR 入口 部における気相の流路面積急縮小の影響が大き く、 $J_{G}$ 増加に伴い気流の縮流に伴う局所圧力損失 が増加したためである。一方、 $J_{L}$ 増加に伴い $\Delta P$ は減少している。これは、 $J_{L}$ 増加に伴い第 1 段 POR 上流の液膜厚さは増加し、POR 入口部の流 路面積の縮小割合が相対的に小さくなり、気相の 縮流による局所圧力損失が低下したためと考え られる。また、POR ギャップ幅の減少により $\Delta P$ は減少している。これは、ギャップ幅の減少によ り、流路のブロッケージ比 (POR 内側流路面積と バレル部流路面積の比）が小さくなったためとい える。POR (Improved)では POR (Normal) と比較す ると定格運転相当条件で $\Delta P$ が約 $43 \%$ 低減してい る。これは、流路のブロッケージ比が小さくなっ たことに加え、POR 下流における流れの剥離の緩 和により、局所圧力損失が減少したためといえる。

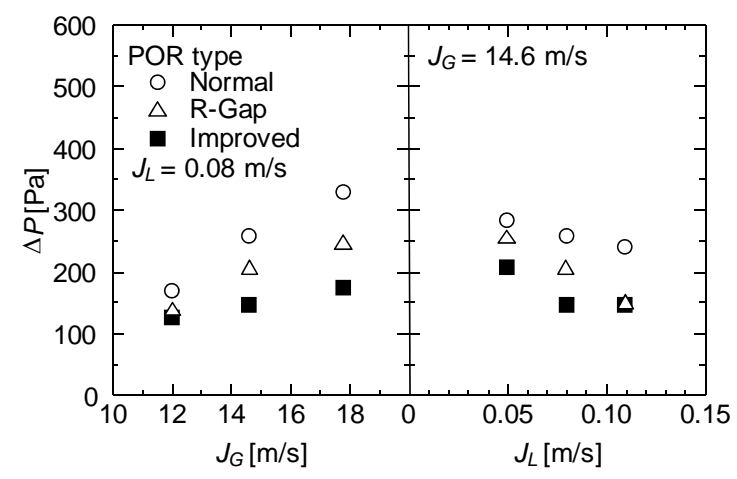

Fig. 11 Effects of POR type on $\Delta P$.

Fig. 12 に液相分離率を示す。POR ギャップ幅 の減少により第 1 段 POR における液相分離率 $W_{s}{ }^{*}{ }_{1}$ は減少している。これは、ギャップ幅の減少 により、液膜及び擾乱波が第 1 段 POR 部から排 水流路側へ流入しづらくなったためといえる。第 2 段 POR における液相分離率 $W_{s}{ }^{*}, 2$ はギャップ幅 の減少により増加している。これは、 $W_{s}{ }^{*},{ }_{1}$ が減少 し 2 段目に流入する液相が増加したためである。 合計液相分離率 $W_{s}{ }^{*}{ }_{T}$ はギャップ幅の減少により 僅かに減少している。これは、第 1 段 POR を乗 り越える液相が増加し、その際に飛散する液滴量 
が増え、再付着せずにガスコアを通過したこと、 及び、2 段目に流入する液相の増加により第 2 段 POR を乗り越える液相が増えたためと考えられ る。POR (Improved)では、ギャップ幅が同じ POR (R-Gap) と比較して $W_{s}{ }^{*}{ }_{1}$ が僅かに減少している。 これは、POR 出口部における流路面積の急拡大が 緩和されたことにより排水流路側への排水が抑 制されたためと考えられる。しかし、第 2 段 POR 部での液相分離により $W_{s}{ }^{*}, 1$ の減少を補っており、 $W_{s}^{*}{ }_{T}$ には大きな減少はみられない。

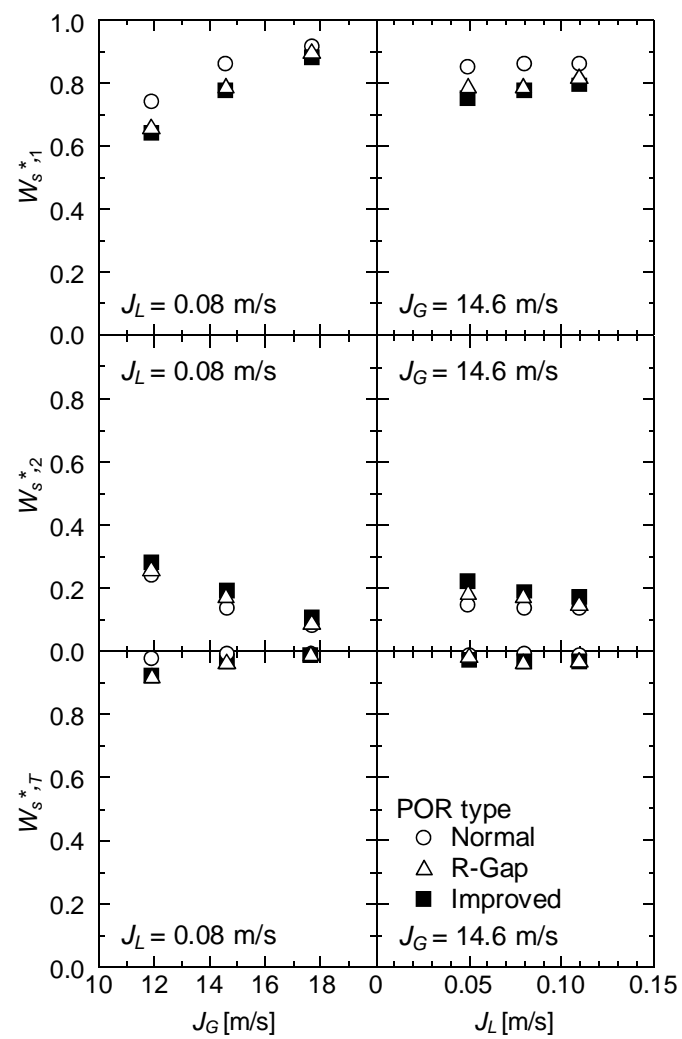

Fig. 12 Effects of POR type on $W_{s}{ }^{*}$.

Fig. 13 にU 測定結果を示す。POR ギャップ 幅の減少によりCUは減少する。これは、ギャッ プ幅減少により、液膜と POR のギャップ部に気 相が流入しにくくなったためである。また、POR (Improved)による CU は、ギャップ幅が同じ POR (R-Gap)による $C U$ とほぼ同じである。このこと から、ギャップ幅 $2.2 \mathrm{~mm}$ では $C U$ に対する POR 下流流路形状の影響は小さいことがわかる。
以上より、Fig. 10 に示した改良型 POR により、 気液分離性能を維持しつつ、圧力損失を低減でき ることを確認した。

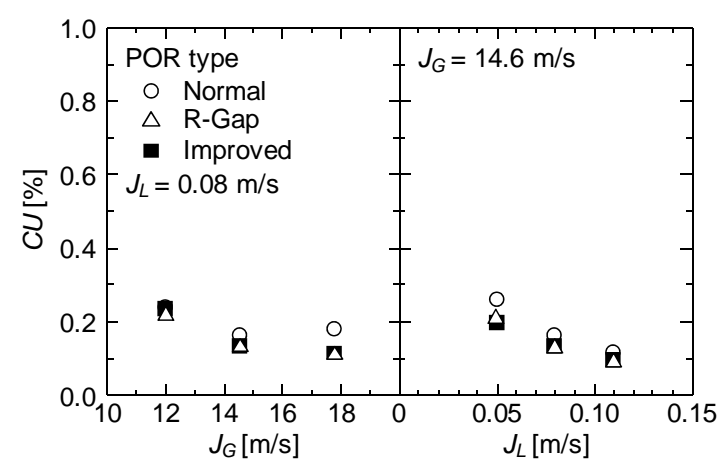

Fig. 13 Effects of POR type on $C U$.

\section{5. 結 言}

気水分離器の第 2 段分離部までを模擬した縮 小試験装置を用いて、流動状態、液相分離率、液 膜厚さ、キャリーアンダー、圧力損失を測定し、 気水分離器の構成要素であるピックオフリング が気液分離特性に及ぼす影響を実験的に調べ、以 下の結論を得た。

（1）気相体積流束の増加に伴い、液相分離率が増 加し、かつ、キャリーアンダーが減少する。 ただし、液膜厚さが薄くなると、ピックオフ リングギャップ部から排出流路へ気相が流 入しやすくなるため、液相体積流束が低い条 件下では、高気相体積流束条件においてキャ リーアンダーが増加する傾向がある。

（2）液相体積流束が液相分離率に及ぼす影響は 小さい。一方、液相体積流束の増加に伴い、 キャリーアンダーは減少する。

(3) ピックオフリングギャップ幅を最大液膜厚 さ程度とし、出口部をディフューザ形状とし た改良型ピックオフリングにより、気液分離 性能を維持しつつ、第 1 段ピックオフリング 部における圧力損失を著しく（約 43\%）低減 できる。

\section{謝 辞}

本研究における実験データ収集及び整理にあ たっては、神戸大学大学院の卒業生である三賀丈 詩氏、また、神戸大学大学院の船橋駿斗氏に協力 頂きました。ここに記して感謝いたします。 


\section{Nomenclature}

$C U$ : carryunder

$D \quad$ : pipe diameter

$J \quad$ : volume flux in the barrel

$[\mathrm{m} / \mathrm{s}]$

$P \quad$ : gauge pressure

$P^{*} \quad$ : non-dimensional pressure

$t \quad:$ time

$W_{G s}$ : separated-gas flow rate

$[\mathrm{kg} / \mathrm{s}]$

$W_{L s} \quad$ : separated-liquid flow rate

$[\mathrm{kg} / \mathrm{s}]$

$W_{\text {Lus }}$ : unseparated-liquid flow rate

$[\mathrm{kg} / \mathrm{s}]$

$W_{s}^{*} \quad$ : ratio of separated-liquid flow

$z \quad$ : axial position from the swirler outlet

[m]

\section{Greek letters}

$\delta_{m} \quad$ : mean value of liquid film thickness measurement data

$\Delta P \quad$ : pressure loss at 1 st POR

$[\mathrm{Pa}]$

\section{Subscripts}

$B \quad$ : barrel

$G \quad$ : gas phase

$L \quad$ : liquid phase

$P \quad$ : plenum

$S \quad$ : standpipe

$T \quad$ : total

$1 \quad$ : first stage

2 : second stage

\section{参考文献}

[1] Wolf, S. and Moen, R. H., Advances in Steam-Water Separators for Boiling Water Reactors, ASME Paper No.73-WA/PWR-4 (1973).

[2] Nakao, T., Murase, M., Ishida, N., Kawamura, T., Minato, A. and Moriya, K., Decreasing of Pressure Loss in BWR Steam Separator (1) (Evaluation Method of Gas-Liquid Separation), Japanese Journal of Multiphase Flow, Vol. 15(4), 382-389 (2001).

[3] Nakao, T., Murase, M., Ishida, N., Kawamura, T., Nishida, K. and Moriya, K., Decreasing of Pressure Loss in BWR Steam Separator (2) (Decreasing Method of Pressure Loss), Japanese Journal of Multiphase Flow, Vol. 15(4), 390-398 (2001).
[4] Ikeda, H., Takigawa, Y., Iwaki, C., Morooka, S., Yamazaki, Y., Yamada, K., Yagii, T. and Soneda, H., Development of Low-Pressure-Loss Steam Separator with Design by Analysis and Test (I) Validation of Analysis Method and Design of Low-Pressure-Loss Steam Separator, Trans. At. Energy Soc. Japan, Vol. 9(2), 109-117 (2010).

[5] Iwaki, C., Yamazaki, Y., Morooka, S., Yamada, K., Ikeda, H., Yagii, T. and Soneda, H., Development of Low-Pressure-Loss Steam Separator with Design by Analysis and Test (II) Verification of the Full-Scale Steam Separator Performance with Improved Swirler, Trans. At. Energy Soc. Japan, Vol. 9(2), 118-124 (2010).

[6] Katono, K., Ishida, N., Sumikawa, T. and Yasuda, K., Air-Water Downscaled Experiments and Three-Dimensional Two-Phase Flow Simulations of Improved Steam Separator for Boiling Water Reactor, Nucl. Eng. Des., Vol. 278, 465-471 (2014).

[7] Kataoka, H., Tomiyama, A., Hosokawa, S., Sou, A. and Chaki, M., Two-Phase Swirling Flow in a Gas-Liquid Separator, J. Power and Energy Syst., Vol. 2(4), 1120-1131 (2008).

[8] Kataoka, H., Shinkai, Y., Hosokawa, S. and Tomiyama, A., Swirling Annular Flow in a Steam Separator, J. Enginnering for Gas Turbines and Power, Vol. 131, 032904 (2009).

[9] Kataoka, H., Shinkai, Y. and Tomiyama, A., Pressure Drop in Two-Phase Swirling Flow in a Steam Separator, J. Power and Energy Syst., Vol. 3(2), 382-392 (2009).

[10] Matsubayashi, T., Katono, K., Hayashi, K. and Tomiyama, A., Effects of Swirler Shape on Swirling Annular Flow in a Gas-Liquid Separator, Nucl. Eng. Des., Vol. 249, 63-70 (2012).

[11] Takamasa, T. and Hazuku, T., Measuring a Film Flowing Down a Vertical Wall Using Laser Focus Displacement Meter (1st Report, Measuring Principle and Film Thickness), Transactions of the Japan Society of Mechanical Engineers, Series B, Vol. 64(617), 128-135 (1998).

[12] Matsunaga, S., Tomita, Y., Nishi, M. and Tsukamoto H., Fluidonics -Foundation and Application- (in Japanese), 82-84, Asakura Publishing, Tokyo (1991). 